\title{
Tourist characterization of the Municipality of Ruiz, Nayarit; to contribute to the touristic development of the region
}

\section{Caracterización turística del Municipio de Ruiz, Nayarit; para contribuir al desarrollo turístico de la región}

\author{
ALTAMIRANO-ROLDÁN, Glafira Eugenia†*， VILLARREAL-BAÑUELOS， Erixander and \\ GARCÍA-GONZÁLEZ, Frasim
}

Universidad Tecnológica de la Costa

ID $1^{\text {st }}$ Author: Glafira Eugenia, Altamirano-Roldán / ORC ID: 0000-0002-8211-4903, CVU CONACYT ID: 1018276

ID $1^{\text {st }}$ Coauthor: Erixander, Villarreal-Bañuelos / ORC ID: 0000-0001-6049-5728, CVU CONACYT ID: 1019548

ID $2^{\text {nd }}$ Coauthor: Frasim, García-González, / ORC ID: 0000-0002-2352-9009, CVU CONACYT ID: 473802

DOI: $10.35429 / J F E .2019 .5 .3 .27 .40$

Received August 25, 2019; Accepted December 14, 2019

\begin{abstract}
The tourist characterization of the communities is a key element in the correct tourist planning, since this allows to obtain technical information about the potential that a site has for its tourist development. This study consists of five parts, the first one includes general data, then information is collected on the elements that make up the tourism system, such as: tourism plant, infrastructure, government and receiving community. The main objective of this research is to know and document aspects and general characteristics of the municipality of Ruiz, looking for the elements of its tourist development, data such as the identification of the offer of accommodation, food and leisure services, infrastructure, as well as type of transport and accessibility that are available to move to the cities that make up the communication routes, health and energy services of the municipality, as well as the most important economic activities and government support that is poured into the municipality. This information is basic in the decision making of investors in tourism developments, both in the community and external. This instrument was applied through interviews with key people, in addition to gathering information through observation about the behavior and perception that the inhabitants of these communities have about the development of tourism in the municipality.
\end{abstract}

Tourist planification, Tourist characterization, Regional Development

\begin{abstract}
Resumen
La caracterización turística de las comunidades es un elemento clave en la correcta planificación turística, ya que esto permite obtener información técnica sobre el potencial que tiene un sitio para su desarrollo turístico. Este estudio consta de cinco partes, la primera incluye datos generales, luego se recopila información sobre los elementos que componen el sistema turístico, tales como: planta turística, infraestructura, gobierno y comunidad receptora. El objetivo principal de esta investigación es conocer y documentar aspectos y características generales del municipio de Ruiz, buscando los elementos de su desarrollo turístico, datos como la identificación de la oferta de alojamiento, alimentación y servicios de ocio, infraestructuras, así como el tipo de transporte y accesibilidad que están disponibles para trasladarse a las ciudades que conforman las vías de comunicación, servicios de salud y energía del municipio, así como las actividades económicas más importantes y apoyo gubernamental que se vierte en el municipio. Esta información es básica en la toma de decisiones de los inversores en la evolución del turismo, tanto en la comunidad como en el exterior. Este instrumento se aplicó a través de entrevistas con personas clave, además de recopilar información a través de la observación sobre el comportamiento y la percepción que los habitantes de estas comunidades tienen sobre el desarrollo del turismo en el municipio.
\end{abstract}

Planificación turística, Caracterización turística, Desarrollo Regional

Citation: ALTAMIRANO-ROLDÁN, Glafira Eugenia, VILLARREAL-BAÑUELOS, Erixander and GARCÍAGONZÁLEZ, Frasim. Tourist characterization of the Municipality of Ruiz, Nayarit; to contribute to the touristic development of the region. RINOE Journal-Financial Economy. 2019. 3-5: 27-40.

\footnotetext{
* Correspondence to Author (email: mdti.martinez@tescha-informatica.net)

$\uparrow$ Researcher contributing first author.
} 


\section{Introduction}

The town of Ruíz, Nayarit is located in the northcentral part of the State of Nayarit. Territorially it borders to the north with the municipalities of Rosamorada and El Nayar, to the south with the municipalities of El Nayar and Santiago Ixuintla, to the west with Santiago Ixcuintla, Tuxpan and Rosamorada and to the east with El Nayar.

Ruíz is located at a variable height that goes from 880 to 1,640 meters above sea level (masl). According to the Ruiz Municipal Development Plan (2017-2021), its physical characteristics make it feasible in the production of tall coffee of both the robust and Arabic varieties, in addition to other agricultural products such as pineapple, mango, chili, Jamaica, Bean, Nanchi, Arrayan, Passion Fruit, Banana, Corn and Vegetables. (Ruiz, Nayarit, 2017). It is formed by a territorial extension of about 900 square kilometers. According to the results that yielded the population count that INEGI carried out in 2015, the total number of population in the municipality of Ruíz is 24,743 inhabitants (INEGI, 2015)

The municipality of Ruíz has several attractive areas where there is a great vegetation where we can find species such as the encino prieto, encino, tepehuaje, papelillo, guapinol, nanche, arrayan, coffee, pineapples, trumpet flower, mayacuyá, jamaica, guamaras, soursop, huisache and capomo blueberries; With respect to its fauna, there are mainly wild animals, among which we can find white-tailed deer, wild boar, badger, armadillo, rabbit, round-dove doves, Aguililla, Pecarí de collar, Carpenter Alirrojo, Picogrueso pechicafé; as species of special protection are the butterfly Sparrow, seven colors and the parakeet Catarina; as a threatened species the Badger and endangered the Green Macaw, (Ruiz, Nayarit, 2017).

Ruiz currently has virgin areas where man has not yet intervened for modification, these are part of the interest of people at regional and national level who seek to know the destination. These areas are formed by natural aspects as the main attraction because it generates a type of environment where people have the opportunity to enjoy what each place has and at the same time perform various recreational and outdoor sports activities.
This is what is known as nature tourism or also known as ecotourism.

It is a series of characteristics of the areas that are considered natural by the environment they have and that have somehow been preserved over time.

Among the attractions that exist in the municipality are the totally natural spas with waterfalls, some of the most visited are the Tenamache stream, El Salto and Malpaso, because they are places where nature is part of each of them and where precisely Alternative tourism is what gives them the opportunity to diversify a tourism product through innovation and creativity.

Other natural resources that the municipality has are forestry and minerals. The former are not properly exploited by the difficult access to the mountains, while the latter are exploited from the mines that exist in the mountain area in the towns of La Frazada, El Zopilote, The Hideaway, the Deer and September 8 , of which gold and silver are the most extracted metals, (Ruiz, Nayarit, 2017), (Mexican Geological Service, 2018).

In addition to this, Ruíz has several attractive areas and buildings where those that are natural, historical, religious and cultural stand out, which makes it an interesting, attractive and important place for tourism development.

The purpose of this research is to present the aspects and characteristics of Ruiz, such as; the supply of services, infrastructure of basic services, government, description of the receiving community, characterization of the demand, and last but not least, describe and characterize the tourist attractions and resources, so that the results obtained serve as part initial of a macro project that contemplates the North zone of the State of Nayarit and that in turn becomes a tool of value that contributes true foundations on the value of the natural resource that the municipality possesses and therefore, contributes in the correct tourist planning and the tourism development of the region. 


\section{Theoretical framework}

\section{Theoretical aspects of regional development and tourism}

Development as a complex phenomenon is not presented in a homogeneous way, it is differentially reflected between spaces showing imbalances, regional disparities and problems that need to be studied to find a solution, a situation that is intensified today by the global relations of society that integrate it with based on the hegemonic model of capitalism and which greatly influences regional and local contexts, establishing diverse territorial logics.

Based on this, it is of fundamental importance to analyze the different theoretical approaches that try to explain the phenomenon of development on a regional scale from the perspective of the capitalist system. In general, the existence of two theoretical approaches in which these theories can be classified is fully recognized, although it is worth noting that in addition to these two general domain approaches, the emergence of a third party can be mentioned, based on the current context where the process of Globalization is growing. In this third approach, new approaches emerge that incorporate the effects of the global scope into the regional or local scope into the analysis. Within the first approach, there are theories based on the neoclassical current that are based on the spatial convergence of development, which fundamentally raise the capacity of market forces to solve spatial imbalances, finding in businessmen and consumers through of its rationalist attitude, the mechanism to reach equilibrium, as it seeks to optimize for the first the return on capital and for the latter the utility in consumption, this group of thinkers and the theories they propose are known as the balanced development approach, (Peña, 2004).

These theories establish that the mechanism to achieve equilibrium is based on the free mobility of productive factors, both capital and labor, the uniqueness of production functions, perfect dissemination of innovations and a tendency to equalize marginal yields and prices in the different territories, the latter being the most important in the process.
This current considers space as a simple process of circular reasoning where any mismatch will be reflected in the prices of productive factors and consumer products, in which market forces will bring the balance back, (Castro, 2009).

The second approach integrated by the theories that maintain spatial divergence as a fundamental premise, considers that regional imbalances and disparities are caused by the dynamics of capitalism itself, stating that market forces cannot eliminate them, requiring the intervention of powers audiences actively, consciously and voluntarily. They consider that space is heterogeneous in the endowment of economic and non-economic factors, creating spatial relationships that produce and reproduce disparities or imbalances or even worsen rather than correct themselves.

The third increasingly consolidated approach includes the new theories of regional development that contemplate the influence of globalization processes at the local level, consider that the territory is an element that significantly influences the development processes of local society, considering it as an active factor in which the relations between resources and the various economic and social actors are carried out, establishing a dialectical relationship between the local and the global.

Peña (2004) establishes the relationship between theoretical currents and their objects of study, mentioning the analogical existence between the three approaches that, as currents of thought, address the aspects: a) convergence theories / models, related to the notion of space / homogeneous region, b) divergence theories / models, related to the notion of nodal and planned space / region, and; c) theories / models of globalization, related by the notion of space / territory / globalization.

In this theoretical context, the coincidence of thought was defined with the authors who criticize the positions derived from the balanced approach, whose base assumptions are unrealistic, with insufficient empirical evidence to support them, since there is no perfect mobility of factors, which conditions and substantially limits the tendency to equal pay in the regions, making this condition almost impossible to achieve, (Asuad, 2001). 
As a consequence, the divergence approach (notion of nodal region space, planned) and the one related to the notion of space, territory and globalization are taken as an explanatory theoretical element, the reason for this position is based on the fact that there is greater empirical evidence in that disparities in income and regional production are the product of market forces that tend to generate imbalance and a continuous and cumulative process of inequality, (Asuad, 2001).

\section{Tourism and regional development.}

Tourism is the economic activity that has had greater dynamism in recent times worldwide, has become the spearhead of global capitalism meaning a very effective vehicle for financial globalization and the world capital movement, (Dachary \& Burne, 2002). According to the World Tourism Organization, tourism activity has grown at annual average rates of up to $7.2 \%$, tourist visits have exceeded the amount of 700 million in 2002, the UNWTO forecasts that by 2020 the tourist visits they will be around 1560 million per year (OMT, 2005). The development of new information and communication technologies will further strengthen the growth of tourism activities, these figures allow us to infer that the tourist phenomenon of increasing importance worldwide will be increasingly important and that the phenomenon of globalization It will boost it even more.

Tourism has become one of the most centralized and competitive industries in the world and almost no other economic sector illustrates so clearly the global reach of transnational corporations. In recent years, the industry has pressured governments around the world to liberalize trade and investment in services, and will likely gain enormous benefits from the General Agreement on Trade in Services, a multilateral pact within the framework of the World Organization of the Commerce (WTO).

Tourism becomes a model within global capitalism as manifested by Dachary \& Burne (2006) and therefore, reproduces all its externalities. The model is real estate, produces spaces and territories with great influences and modifications of economic, social, political, cultural and environmental structures (Rubio, Torres \& Velazquez, 2014)
The capitals determine their movements and move from distant areas to the tourist spaces they build, always obeying the logic of the market, in many cases they cause high social costs assumed by the receiving groups that become societies controlled by tourism developers and entrepreneurs, ( Dachary \& Burne, 2006).

The complex nature of tourism leads it to manifest itself as a phenomenon in various contexts. The regional scope is one of the most relevant insofar as it requires a space for its development, it is a builder and consumer of spaces and landscape modifier (Asaud, 2001)

Dachary \& Burne (2004), clearly establish the relationship between tourism and regional development using the approaches of Panosso (2012), Álvarez \& López Cordova, (2010) and Milton Santos (1996) based on the conception of space, taking it as an abstract reality or as a dialectical abstraction, where both material objects and human actions converge, typified as geographical objects, natural objects and social objects that manifest in dynamics that characterize them identified through the relationships established between these sets that in turn have the capacity to generate new relationships, giving particularity to the spaces and the society that is in them, that is, the spaces begin to find their identity from this dynamic and are built socially and historically.

Tourism is part of human activity and as such is carried out in a spatial area, creates and appropriates territories by significantly modifying the structures formed by the relationships between objects of geographical, natural and social nature that are originally settled in the spaces, their implications and effects of various kinds, have made the theoretical principles of thinkers such as Perroux, which consider cities as the ideal poles that favor the creation of complex networks that produce so much, are retained by the governments of multiple countries. economies of scale and external economies that facilitate the accumulation of capital (Santana Talavera, 1997) 
As a result of these actions, the so-called tourist development poles have emerged, which are nothing other than tourist cities created ex professingly creating relationships and modifications to the economic, social, environmental, political and cultural environment of great magnitude. Moreover, tourist corridors have emerged in which the poles are combined and spatially enlarged, resizing the effects of tourism on space, territories and regions on a larger scale, generating differentiated conditions in the development process.

The multiplier effect of tourism establishes linkages back and forth in many of the economic activities, which gives dynamics to regional economies generating jobs, changes in the structure of income and consumption, but also generates inflationary pressures, insufficient food supply and other goods for resident populations, population movements that also put pressure on public services, housing and, in general, on the standard of living, tourism uses natural or cultural resources that, depending on their forms of consumption, can lead to degradation and irreversible harmful effects.

\section{Alternative tourism}

It is a set of alternative activities that are presented as the new trends of society in general, since they are carried out in a rational way and with great attachment to sustainability. The tourist seeks to have a closer contact with nature or have new experiences in a unique environment. All this as a result of the damage and inequality that is reflected in all tourist destinations in which there is great pollution, exploitation and shortage of natural resources, such as water; as well as the loss of identity of the local population, (Ibáñez \& Rodríguez 2012). These activities are emphasized in an economic development in which the community receives equitably the income obtained and provides more support for the opening of local businesses, in addition to environmental conservation. Since, if it continues to be overexploited, it will increase the imbalance in the ecosystems and a social development that implies a well-being and improvement of the quality of life of the inhabitants, as well as their integration in the labor aspects, (Ibáñez \& Rodríguez 2012).
In summary, this tourist modality has the purpose of carrying out trips that allow tourists to participate in recreational activities in contact with nature and cultural expressions of rural, indigenous and urban communities, respecting the natural, cultural and historical heritage of the place visited . It is known as the set of tourist modalities that aim to be consistent with natural, social and community values, also allowing both hosts and tourists to enjoy a positive interaction and shared experiences. It is worth mentioning that this modality is made up of activities such as: cultural tourism, rural tourism, agrotourism, ecotourism, adventure tourism, hunting tourism, among others. (Santos, 1996)

\section{Ecotourism}

Ecotourism according to Ibáñez \& Rodríguez (2012), is a new conservative movement based on the tourism industry, which is defined as responsible trips that preserve the environment and sustain the well-being of the local community. It is accompanied by ethical codes and a huge group of international travelers, students, thinkers; It has the support of the governments of a large number of countries. It seeks education and recreation by observing and studying the values of the place, and its development must generate resources for its preservation and for the community.

Among the main activities carried out in ecotourism are: education workshops, hiking, sidereal observation, rescue of flora and fauna, observation of flora, observation of ecosystems, geological observation and observation of natural attractions. Within the following table the definition of some of these activities is carried out: 
December 2019 Vol.3 No.5 27-40

\begin{tabular}{|c|c|c|}
\hline $\begin{array}{l}\text { Type of } \\
\text { Tourism }\end{array}$ & Activity & Definition \\
\hline \multirow[t]{3}{*}{ Ecotourism } & $\begin{array}{l}\text { Interpretive } \\
\text { hiking }\end{array}$ & $\begin{array}{l}\text { Activity where the } \\
\text { visitor travels on foot } \\
\text { or in a non-motorized } \\
\text { transport, on a } \\
\text { predefined cross } \\
\text { country road and } \\
\text { equipped with } \\
\text { information cards, } \\
\text { signs and / or guided } \\
\text { by nature interpreters, } \\
\text { whose specific } \\
\text { purpose is the } \\
\text { knowledge of a } \\
\text { natural environment. } \\
\text { The tours are } \\
\text { generally of short } \\
\text { duration and } \\
\text { educational } \\
\text { orientation. }\end{array}$ \\
\hline & $\begin{array}{l}\text { Sidereal } \\
\text { Observation }\end{array}$ & $\begin{array}{l}\text { Appreciation and } \\
\text { enjoy the } \\
\text { manifestations of the } \\
\text { open field cosmos. } \\
\text { Traditionally } \\
\text { associated with stellar } \\
\text { observation, with the } \\
\text { increasing use of } \\
\text { specialized } \\
\text { equipment the range } \\
\text { of objects observed } \\
\text { has expanded to large } \\
\text { expressions of the } \\
\text { universe }\end{array}$ \\
\hline & $\begin{array}{l}\text { Environmental } \\
\text { education } \\
\text { workshops }\end{array}$ & $\begin{array}{l}\text { Didactic activities, in } \\
\text { direct contact with } \\
\text { nature and where } \\
\text { possible involving } \\
\text { local communities; } \\
\text { Its purpose is to } \\
\text { sensitize and raise } \\
\text { awareness among } \\
\text { participants of the } \\
\text { importance of } \\
\text { relationships between } \\
\text { the different elements } \\
\text { of nature. }\end{array}$ \\
\hline
\end{tabular}

Table 1 Classification of Ecotourism activities Source: own elaboration with data taken from the Ministry of Tourism (SECTUR), 2004

\section{Adventure trip}

Some call it sports tourism, others more, adventure tourism, others, adrenaline tourism or challenge tourism, and although its name is not important, the concepts do become decisive.

So these denominations generate confusion and concerns among tourists and even among providers and marketers of these services, (Ibáñez \& Rodríguez, 2012). Regarding the activities that are practiced within this modality we find:

\begin{tabular}{|c|c|c|}
\hline $\begin{array}{c}\text { Type of } \\
\text { Tourism }\end{array}$ & Activity & Definition \\
\hline \multirow[t]{7}{*}{$\begin{array}{l}\text { Adventure } \\
\text { trip }\end{array}$} & Abseiling & $\begin{array}{l}\text { Fixed rope descent } \\
\text { technique, with the help } \\
\text { of specialized } \\
\text { equipment and } \\
\text { techniques. Generally } \\
\text { performed in open } \\
\text { spaces and vertically. }\end{array}$ \\
\hline & Climbing & $\begin{array}{l}\text { It implies the ascent } \\
\text { through rock walls } \\
\text { using hands and feet as } \\
\text { an element of } \\
\text { progression. The use of } \\
\text { specialized techniques } \\
\text { and equipment allows } \\
\text { safe movement. A } \\
\text { contemporary version is } \\
\text { artificial walls } \\
\text { (bouldering). }\end{array}$ \\
\hline & Ride & $\begin{array}{l}\text { Horseback riding in } \\
\text { natural areas; The main } \\
\text { objective is the } \\
\text { experience of riding and } \\
\text { knowing about the } \\
\text { handling and habits of } \\
\text { these animals. }\end{array}$ \\
\hline & Mountaineering & $\begin{array}{l}\text { Considered as a sport, it } \\
\text { is defined as the } \\
\text { discipline that consists } \\
\text { of hiking in the } \\
\text { mountains. }\end{array}$ \\
\hline & Hike & $\begin{array}{l}\text { This activity is one of } \\
\text { the most widely } \\
\text { accepted and demanded. } \\
\text { Preferential walking } \\
\text { routes or circuits must } \\
\text { be previously } \\
\text { established and dosed } \\
\text { according to the profile } \\
\text { of the tourist who is } \\
\text { going to practice it } \\
\text { (children, youth, adults, } \\
\text { senior citizens, small or } \\
\text { large groups. }\end{array}$ \\
\hline & Caving & $\begin{array}{l}\text { Activity that consists of } \\
\text { descending in caves, } \\
\text { caves, basements and } \\
\text { caverns and } \\
\text { appreciating the } \\
\text { different geological } \\
\text { structures, flora and } \\
\text { fauna. Caving is a } \\
\text { discipline that has } \\
\text { scientific and research } \\
\text { purposes; Caving has } \\
\text { recreational and } \\
\text { appreciation purposes. }\end{array}$ \\
\hline & Mountain biking & $\begin{array}{l}\text { Cross-country tour } \\
\text { using as a medium an } \\
\text { all-terrain bike. The } \\
\text { activity takes place on } \\
\text { dirt roads, gaps and } \\
\text { narrow paths with } \\
\text { varying degrees of } \\
\text { technical difficulty and } \\
\text { physical effort. }\end{array}$ \\
\hline
\end{tabular}

Table 2 Classification of Adventure Tourism activities Source: own elaboration with data taken from the Ministry of Tourism (SECTUR), 2004 


\section{Rural tourism}

According to Ibáñez, \& Rodríguez, (2012), rural tourism is that type of tourism that takes place in non-urban areas, enhancing the culture, values and identity of the local population, through its direct and active participation in the provision of tourist services. Traditional tourism activities complement this type of tourism and allow positive exchange between visitors and recipients. It should be clarified that it does not necessarily link visitors with agricultural activities. Finally, it is worth noting that the main motivations for the practice of this tourist modality are: the contemplation of specific areas, landscape, recreation and, of course, rest.

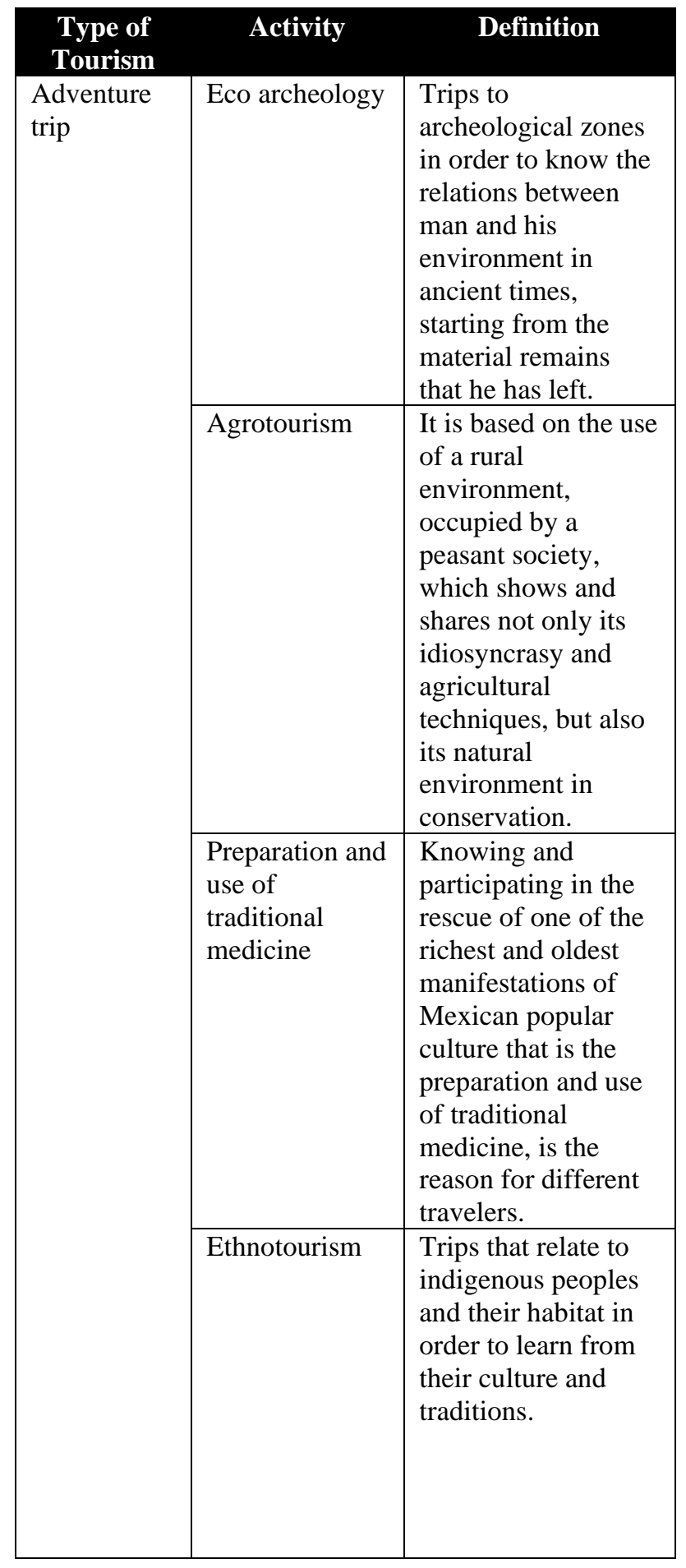

\begin{tabular}{|c|c|}
\hline $\begin{array}{l}\text { Gastronomic } \\
\text { Workshops }\end{array}$ & $\begin{array}{l}\text { These activities are } \\
\text { motivated to learn, } \\
\text { prepare and taste the } \\
\text { gastronomic variety } \\
\text { offered by the hosts } \\
\text { of the visited places. }\end{array}$ \\
\hline $\begin{array}{l}\text { Craft } \\
\text { Workshops }\end{array}$ & $\begin{array}{l}\text { This experience is } \\
\text { based on } \\
\text { participating and } \\
\text { learning the } \\
\text { elaboration of } \\
\text { different crafts in the } \\
\text { scenarios and with } \\
\text { the native } \\
\text { procedures. }\end{array}$ \\
\hline $\begin{array}{l}\text { Dialect } \\
\text { learning }\end{array}$ & $\begin{array}{l}\text { Travel with the } \\
\text { motivation to learn } \\
\text { the dialect of the } \\
\text { place visited, as well } \\
\text { as their customs and } \\
\text { social organization. }\end{array}$ \\
\hline $\begin{array}{l}\text { Rural } \\
\text { photography }\end{array}$ & $\begin{array}{l}\text { This activity is of } \\
\text { great interest for } \\
\text { those travelers who } \\
\text { like to capture in } \\
\text { images the different } \\
\text { cultural } \\
\text { manifestations and } \\
\text { natural landscapes } \\
\text { of the rural } \\
\text { environment. }\end{array}$ \\
\hline $\begin{array}{l}\text { Mystical } \\
\text { experiences }\end{array}$ & $\begin{array}{l}\text { It offers the } \\
\text { opportunity to live } \\
\text { the experience of } \\
\text { knowing and } \\
\text { participating in the } \\
\text { richness of the } \\
\text { beliefs, legends and } \\
\text { divine rituals of a } \\
\text { people, inherited by } \\
\text { their ancestors. }\end{array}$ \\
\hline
\end{tabular}

Table 3 Classification of Rural Tourism activities Source: own elaboration with data taken from the Ministry of Tourism (SECTUR), 2004

\section{The tourist system and its elements}

The tourism system is a conceptual process model formed by a set of elements arranged according to their functions and their spatial location, which are rationally linked to each other through the principles or rules of the market (supply, demand and regulation), maintaining their Once exchange relations with other systems of different rank. Like any conceptual system, it comes from a real system and is parallel adjusting methodologically and symbolically, facilitating the analysis and understanding of said real system and it is in this sense that its importance lies as a research tool. 


\section{Composition}

It is appropriate to analyze tourism from an overview, as a system in which you can define its parts and specify links between them. The tourism system is composed of a set of heterogeneous elements that are closely linked to each other and in constant dynamism. According to the model of Sergio Molina (2006), the tourism system consists of 6 elements that pursue a common objective:

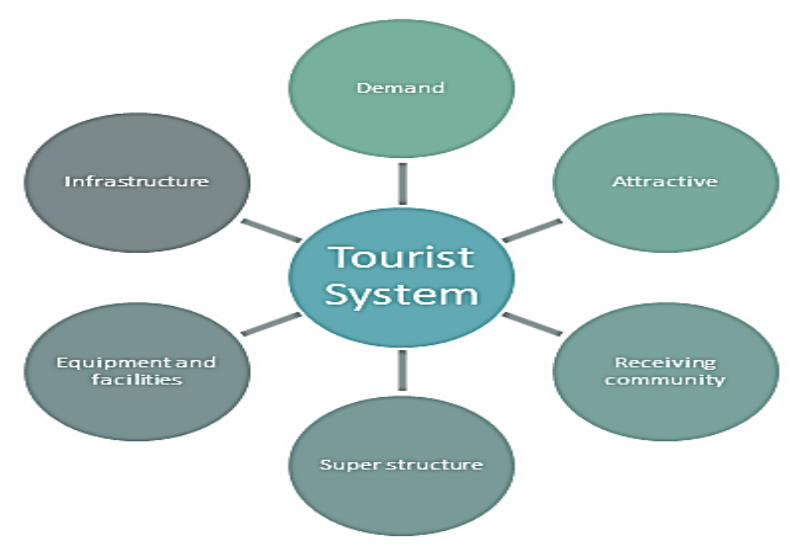

Figure 1 Molina Tourist System

Source: Molina (2006)

\section{Tourist attractions}

They are places that arouse the interest of tourists to visit a destination thanks to its outstanding tangible and / or intangible characteristics. A destination to be considered attractive must be competitive and to achieve this, the motivations that prompted visitors to travel to it must be satisfied. The tourist attractions of a destination are divided into natural such as parks, deserts, beaches, etc., and cultural such as gastronomy, folklore and the architecture of its monuments and historical sites.

\section{Superstructure.}

They are public and private organizations that represent service providers in the tourismrelated sectors, in the same way that policies are established, they look after the interests of their members, develop projects and encourage investment. In Mexico there are, for example: the Ministry of Tourism (SECTUR), the Ministry of Economy, the National Chamber of the Restaurant of Food and Spiced Food (CANIRAC), the Ministry of Environment and Natural Resources (SEMARNAT), the National Development Fund to Tourism (FONATUR), etc.

\section{Infrastructure.}

Defined by the dictionary of the Royal Spanish Academy as the set of elements, endowments or services necessary for the proper functioning of a country, a city or any organization.

In the case of the tourism sector, they are the indispensable communication routes so that the traveler can move in and out of the tourist destination. There are 3 types of infrastructure: (1) Maritime, (2) Terrestrial and (3) Aerial.

\section{Services (offer).}

In the tourism system we find 2 types of services, the basic ones such as hotels, travel agencies and restaurants, that is, those properties that a tourist needs fundamentally when traveling; and complementary services, which do not intervene directly with the tourist but are necessary, examples of these are banks, exchange houses or gas stations.

\section{Demand (tourists).}

None of the above elements could survive without tourists. They constitute the counterpart of the law of supply and demand, that is, they are the ones who consume, use and / or benefit from what destiny has to offer; In addition, it is from his experience, that within the destination strategies can be established to meet their needs in a better way, encouraging the development of the receiving community.

The receiving community.

These are local residents who directly (such as tourism service providers) or indirectly (general population or human resources of various companies) have contact with the tourism community.

For its part, the World Tourism Organization (UNWTO, 1991) focuses the tourism system on 4 elements, with demand, supply, geographical space and market operators. Roberto Boullón (2006), proposes the following elements: demand, supply, infrastructure, superstructure, attractions and facilities. 
Demand: it is the most dynamic component of the system and involves the group of people (current or potential) who travel and make use of the services and facilities created for recreation. From a socio-economic point of view, demand is determined by the ease of access to transport, income, educational level and the desire to get out of the routine; Tourism demand is generated when society has generally exceeded a level of income sufficient to cover basic needs. On the other hand, societies with large polarizations in the concentration of wealth will generate a limited or restricted tourist demand. The offer: it is the set of elements that make up the tourist experience, that is, it is composed of those elements that attract tourists to the destination and meet their needs and expectations. This distinguishes the following components: tourism resources and attractions, tourism silver (companies related to the sector), infrastructure and institutional elements (public and private institutions involved in tourism development). Resources and tourist attractions: those elements that motivate the movement of tourists. They can be of natural, cultural origin, etc. It is possible to differentiate between resources and attractions being the first potential attractions while the second are those resources already valued. The tourist plant: they are all the companies that facilitate the stay of the tourist in the destination providing services of lodging, restoration, recreation, displacement, etc. The infrastructure: they are all those elements that provide services not exclusively tourism and that in the first place seek the satisfaction of the local population but without which it would be impossible the operation of tourist services would be impossible. These are roads, railways, ports, airports, communications, energy networks, drinking water and wastewater, waste collection systems, etc. Some authors make the distinction between infrastructure and supporting infrastructure, referring to the first as those static elements and to the second as those that are transformed according to needs. (ex: infrastructure: an air route, a sea route; supporting infrastructure: an airport or a sea port). The institutional elements: are tourism legislation in general, public, private or mixed tourism entities, promotional actions, facilitation to private companies, that is, all activities carried out by the public sector in tourism. This element is also called as a superstructure and is responsible for ensuring the overall functioning of the entire system.
From this it follows that the more important the tourist activity for the region, the stronger and more efficient the superstructure that manages said territory should be.

\section{Tourist System proposed by Roberto Boullón}

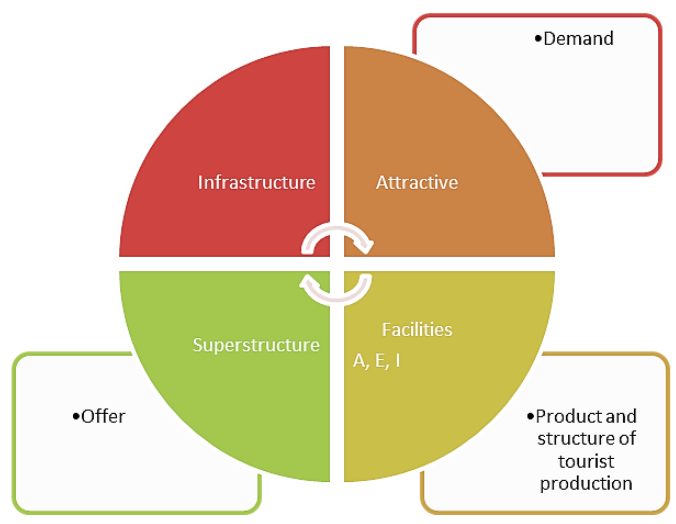

Figure 2 Roberto Boullón Tourist System Source: Boullón (2006)

Although these authors represent different approaches to visualize the tourism system, the actors are fundamentally the same, however the difference lies primarily in relation to the tourist space according to the UNWTO (2005) and supra structure of Boullón (2006), the latter according to approach to the tourist system that is more focused on the economic activity it produces, instead it will see an overwhelming appreciation of the elements of the tourist system, something more territorial.

\section{Importance of Tourism Planning}

To work in the tourism development of a country or to promote it, it is essential to carry out a series of actions that must be aimed at achieving specific and well-defined objectives, and then translate them into a coherent and integrated development plan. According to Ander-Egg, E. (2007), planning is rationally anticipating the actions to be carried out based on the resources and objectives that are to be achieved to generate transformations. That is to say, that planning is the decision of the way in which the things that are at hand will be used to reach the point where you want to arrive. It is believed that tourism provides a country with substantial socioeconomic benefits and, for this reason, many countries, developed and underdeveloped, see in these activities an opportunity to achieve sustained growth, a stable source of foreign exchange and an instrument of generation of employment. 
However, the country is required to have a series of preconditions, including a combination of natural, scenic, historical, archaeological, natural and climatic attractions. Tourism is also not a panacea for the development of a country, as it certainly has great advantages but also has harmful effects and consequences. It is then advisable to count the advantages and disadvantages known as tourism development, which supports the importance of careful planning, (Quijano, 2009).

\section{Concept and Importance of Tourist Diagnosis}

Diagnostic Concept. The tourist diagnosis is a study whose main objective is to know the current and potential situation of the tourist activity in the commune. To carry it out it is necessary to analyze both its strengths and weaknesses, as well as its opportunities and threats (SWOT Analysis) (Quijano, 2009).

\section{Importance of Tourist Diagnosis.}

The diagnosis includes the analysis of: the current situation, the historical situation and the main obstacles to development and indicates the prospects for progress in response to the resources and potential of the geographical space, at the subregional and regional level and the existing structural conditions. In this primary phase of planning it is intended to detect the main obstacles that impede the fulfillment of the image and the identification of the potentialities that could help to achieve it.

\section{Diagnostic functions.}

- Dimension the distance and the difference between the actual current situation and the ideal future situation that this implies in the definition of objectives.

- Corroborate and confirm the objectives set at specific levels.

- Provide the conditions that confirm and rectify the deadlines set for achieving the objectives.

- Define and explain those internal or external variables that may constitute an obstacle to said process.
- The diagnosis involves, among other areas, raising an inventory of resources and attractions that will allow us to know, among other aspects, the five different tourism products, the stage in which each of the products is located: introduction, stabilization and the type of demand that motivates.

\section{Methodology}

The present investigation is considered qualitative, of a transversal type with a mixed approach and with an exploratory scope, since it describes aspects and characteristics of the municipality of Ruiz. The primary sources of the research were through direct subjects such as the population where the on-site visits were made in the municipality, the City Council where information on support programs and contributions to localities and service providers were obtained for Know the services they provide both in accommodation and lodging. Also in the visit, aspects and some characteristics could be observed about the general day-to-day environment of the towns (Sampieri, 2018)

For the collection of the information, the tourist characterization sheet of communities was used, which served to obtain data such as general information and demographic data of the municipality, identification of the offer of food, lodging and recreation services, to know the infrastructure of basic services, the type of transport used, accessibility, the type of communications, health, energy, some aspects of local government as well as the main economic activities of the municipality (Schulke Silke, 2003)

\section{Results}

Below are the results that were obtained in the present investigation, which were obtained through the tourist characterization sheet of communities, which served as a parameter to obtain other data such as general information of the locality, identification of the offer of lodging, food and recreation services, knowing the basic services infrastructure as well as the type of transport and accessibility, communications, health and energy as well as the most important economic activities and government support poured towards the town. 
Service offer.

Lodging. The municipality of Ruiz has 6 hotels, 5 motels and 1 pension that serve to provide accommodation to tourists, which can be deduced that it has a hotel floor that allows to develop tourism activity.

Feeding. There are restaurants of different types of food, mainly of local cuisine and Mexican snacks, 22 lunch boxes, 2 bars that provide night service, 9 canteens and 15 funds including those of the local market, as well as street stalls that offer various types of food such as tacos, Burgers and seafood. On the way out to the town of El Venado there is a Salvadoran food stop and a birrería. In the town of Venado they have 1 restaurant based on meat and seafood, as well as 3 home-made food and sale of charcoalroasted chickens.

Spreading. In this area, according to the information collected, it was known that the community has natural water spas and streams, 2 sports facilities and that it totally lacks recreational places such as discos, cinemas, and camps. It has spaces for sports activities, one in the municipal seat, sports facilities with equipment for gymnastics activities in the town of the Station and a multipurpose court in the town of Puerta de Platanares and Nayar.

Other services. As part of the complementary services, there are no travel agencies, tour operators, tourist information modules, there are 3 banks and 4 ATMs, however, the community also does not have trained and certified tourist guides to carry out the activity of tourist guides.

\section{Basic Services Infrastructure.}

Transport and accessibility. Ruíz is located $63 \mathrm{~km}$ from the state capital and $24 \mathrm{~km}$ from the municipality of Santiago Ixcuintla. The distance that exists from Ruiz and the town of El Venado is $16 \mathrm{~km}$ from the municipal capital, the Tenamache of $25 \mathrm{~km}$, the Real del Zopilote 27 $\mathrm{km}$ and the Town of El Nayar $270 \mathrm{~km}$.

The main access road to the community is paved, paved and in very good condition, you can also enter the different locations mentioned above by land with paved road, it has road signs but not tourist.
There is a Costa and Sierra Transportation terminal for travelers that go from the Capital to the mountain area with daily departures as well as the Transportes del Nayar that goes to the municipal seat with hourly departure frequency, within the entire municipality, we can find another type of transport that is more common than the combis with some routes to the different locations such as El Venado, Puerta de Platanares, La Bolita, El Refugio, El Zopilote and the neighboring municipalities of Santiago, Peñas and Tuxpan with a frequency of 15 to 30 minutes, it also has 2 permanent bases of local taxis for transfers over shorter distances.

Communications The locality of Ruiz has local and cellular telephone service, the nearest telephone office is $16 \mathrm{~km}$ away in the municipality of Tuxpan, but nevertheless there are self-service and convenience stores where you can make your payments. In the town there are 2 telephone service booths and in the surrounding towns with public telephone booths, 4 Internet cafes, 6 Mexico broadband sites connected for public internet use and a post office in Mexico. It should be noted that in most of the towns in the municipality there is a mobile phone service.

Health. $29 \%$ of the municipality have installation to the public network of piped water treated with chlorine, water is also used from wells, streams, springs and rainwater.

With respect to the drainage and sewerage system, $88 \%$ of the population has this service, the rest have latrines for the elimination of excreta. The majority of the population disposes of garbage through a collection car as part of municipal services and in locations that do not have this service, the garbage is burned.

In the health services, there is an IMSS clinic, a State Health Services Health Center, an ISSSTE interconsultation clinic as well as some medical services in the offices of the DIF. On the other hand also in the surrounding communities there are 2 mobile health units, 7 health clinics, however, as in most communities in rural areas, there are health houses with authorized personnel and trained with traditional healers, more However, the population uses the health centers located in the towns of Cordón del Jilguero, Presidio de los Reyes and El Naranjo very often 
Energy. $95 \%$ of the population have electric power service, which directly benefits the entire municipality.

Type of government. The municipality of Ruiz has a City Council, which is made up of the Municipal President, the Trustee and seven Aldermen, with their respective alternates. The Regidores are five of relative majority and two of proportional representation.

In accordance with the Organic Law for the Municipal Administration of the State of Nayarit, in force, the auxiliary authorities of the Municipality are: I. The Municipal Commission of Human Rights and Administrative Justice; II. The Delegates and Municipal Commissioners; III. The Auxiliary Judges of each locality; and, IV. The Heads of the urban sector, rural or apple section who have the main purpose of Coadyuvar to fulfill the purposes of the town hall, attend in the regions and localities in which they are determined, the maintenance of tranquility, security and public order, as well as Seek compliance with the Legal, Administrative and Regulatory Ordinances of the Municipality. The Law itself also establishes auxiliary organisms of the city council, which are, the Municipal Collaboration Councils and the Citizen Action Committees who will have the purpose of contributing to the fulfillment of the purposes of the city council and participating through work and solidarity in the neighborhood, civic development and of collective benefit.

Receiving community. The most important economic activities of the municipality are agriculture, in which $68.6 \%$ of the local population is engaged in this activity and in the background is livestock and in third place with $31.4 \%$ forestry and fishing activities.

Within the community there are no formal or informal tourist jobs, there are only tourist services offered by the Travesía Cora company but this company is from the State Capital without a local presence, this offer tourist tours such as the pineapple route and canyoning activities and waterfall waterfall in the Tenamache stream.
In 2017, the community as a whole participated in the workshops for the proposal of the 2017-2021 municipal development plan, citizen participation was given through the selection through the work of participatory mapping, which consisted of identifying on a map the areas or points of greatest problem in order to have a zoned map, as well as the direct participation of the attendees.

In addition to this, the population wrote the problem, needs, ideas and projects on sheets that were delivered to each of them and, simultaneously, also opened to express their opinions openly to the moderators of the workshop.

In this way, three thematic tables were established, which were defined in coordination with the city council, which were designated as the 3 strategic axes that would work in the development of the municipality, thereby showing the opening for the integration of communities for development of local strategic plans. Once the above information is obtained, it can be deduced that tourism is not the main economic activity in the region despite having the necessary tourist resources to develop and enhance this activity, the municipality does not have the human capital trained to be able to provide tourist services, there is no presence of tour guides locally and therefore there is no staff that speaks English as a second language that facilitates attention to foreign tourism. Regarding the attitude of the municipality towards the tourist activity, it was found that $50 \%$ of the respondents considered tourism as an important instrument of development; $30 \%$ consider it as an alternative and seasonal economic activity since the most offered service are the spas in the rainy season and only 3 spas provide services charging access to the site the other streams are free to use; $40 \%$ said they had an indifference to the local development of tourism activity and $20 \%$ expressed disinterest in developing tourism activity since they consider it dangerous and do not believe they solve their economic problems.

\section{Acknowledgments}

We thank the Academic Unit of Economics of the Autonomous University of Nayarit, and in particular Dr. José Octavio Camelo Avedoy, for developing this project and becoming part of the publication. 
Tourism development in the state of Nayarit is a means to achieve local communities. It is a basic element to really seek that social and economic development that is so desired. Ecorfan as editorial of academic works has managed to establish a network of academics prepared for them to publish, and share the progress of their research, socialize them so that they have a greater impact.

We thank all the local actors who have allowed us to have their knowledge of local tourism development, in addition to sharing a long-term project that will seek to improve their social and economic conditions for the best human development of these populations.

\section{Conclusions}

The municipality of Ruiz, Nayarit has great potential for the development of eco-tourism, this as an ideal means to channel social and economic development and achieve the full human development of the members of the Ruiz communities. It has a combination of necessary elements for how Santos (1996) handles it, and Ibañez \& Rodríguez (2012) can develop alternative tourism, basically ecotourism, adventure tourism and rural tourism. Taking into account the model of Molina (2006) there is the first aspect of the tourism system, which is the tourist attraction. With a vast geography with potential for ecotourism, an important demand for its attractions can be generated.

In the other elements of the system is where the main challenge is to develop, and although it has the necessary infrastructure, since it has communication channels, services, demand and the receiving community.In every aspect it can be refined, but especially in the receiving community, since it has not been developed for tourist attention, they have always seen the tourist processes too far from them, so even elements such as the treatment of tourists, development of spaces to take food, service, lodging, among others are what limits the tourism development of the region. Following the model of the World Tourism Organization (1991), the receiving community is once again the element of greatest development potential, so that decision makers will be able to determine the processes of modification of perceptions and attention of the entire population of the region.

\section{References}

Álvarez, U. C., \& López Córdova, J. H. (2010). Desarrollo Regional y Turismo: Revisión Histórico Estructural de la Riviera Nayarit, México TURyDES, 3(8).

Ander-Egg, E. (2007). La planificación estratégica. Buenos Aires: Lumen.

Asuad, N. (2001). Economía regional y urbana. Introducción a las teorías, técnicas y metodologías básicas. México, BUAP.

Boullón, R. C. (2006) Planificación del espacio turístico. México: Trillas.

Castro, U. (2009). Estructuras regionales emergentes y desarrollo turístico sustentable: la región costa sur de Nayarit, México (Doctoral dissertation, Tesis doctoral en Ciencias para el desarrollo sustentable de la Universidad de Guadalajara, México).

Dachary, A. C., \& Arnaiz Burne, S. M. (2002). Globalización, turismo y sustentabilidad, Puerto Vallarta, CUC - UDG.

Dachary, A. C., \& Burne, S. M. A. (2004). Desarrollo y Turismo en la Costa de Jalisco. Puerto Vallarta, CUC - UDG.

Dachary, A. C., \& Burne, S. M. A. (2006). Territorio y turismo: nuevas dimensiones y acciones. Puerto Vallarta, CUC - UDG, Recuperado en: http://www.inafed.gob.mx/work/enciclopedia/E MM18nayarit/municipios/18011a.html $(05 / 10 / 2019)$

Ibáñez, R., \& Rodríguez, I. (2012). Tipologías y antecedentes de la actividad turística: turismo tradicional y turismo alternativo. Medio ambiente y política turística en México, 1, 17-33.

INEGI (2015). Banco de datos de Población. Recuperado en: https://www.inegi.org.mx/temas/estructura/defa ult.html\#Mapas

Molina, S. (2006). El posturismo: turismo y posmodernidad. Trillas.

OMT. (2005) Barómetros del Turismo Mundial, Volumen 3, No. 2, Junio, Madrid, Organización Mundial del Turismo. 
Panosso, A. \& G. Lohmann (2012). Teoría del turismo: conceptos, modelos y sistemas, Trillas, México.

Peña, A. R. (2004). Las disparidades económicas intrarregionales en Andalucía. Servicio de Publicaciones de la Universidad de Cádiz.

Quijano, C. R. (2009). Manual para el diagnóstico turístico local. Guía para planificadores. Guayaquil, Ecuador, Recuperado en: http://unrn.edu.ar/blogs/pt/files/2013/03/6Ricaurte09-GuiaPlanTuris-ver-fichas-al- finalpost-2007.pdf (08/06/2019).

Rubio, R., Torres, K. \& Velásquez, J. (2014). Diagnóstico del Potencial Turístico del Puerto de la Libertad como Polo de Desarrollo de El Salvador, (tesis de grado). Universidad Tecnológica de El Salvador.

Ruiz, Nayarit (2017) Plan de Desarrollo Municipal de Ruiz, Nayarit; 2017-2021. Tepic, Diario Oficial del Estado de Nayarit, Recuperado en: http://www.ruiznayarit.gob.mx/trans39/PDM20 18.pdf (10/08/2019).

Sampieri, R. H. (2018). Metodología de la investigación: las rutas cuantitativa, cualitativa y mixta. McGraw Hill México.

Santana Talavera, A. (1997). Antropología y turismo:¿ nuevas hordas, viejas culturas? Ariel, Barcelona.

Santos, M. (1996). De la totalidad al lugar. Barcelona. Oikos-Tau.

Schulte Silke (2003): Guía conceptual y metodológica para el desarrollo y la planificación del sector turismo. Santiago de Chile: Naciones Unidas.

SECTUR, S. D. (2004). Turismo alternativo, una nueva forma de hacer turismo.

Servicio Geológico Mexicano (2018).Panorama Minero del Estado de Nayarit. Recuperado en: http://www.sgm.gob.mx/pdfs/NAYARIT.pdf (08/10/2019). 